\title{
KASVATUS\&AIKA
}

Katsaus

https://doi.org/10.33350/ka.110646

\section{Saksalainen reformipedagogiikka demokratian edistäjänä}

\author{
Jyrki Hilpelä
}

\section{Uusi koulu}

Kun Thomas ja Katia Mannin vanhimmat lapset - Erika ja Klaus - vielä kouluikäisinä yhä useammin karkasivat Münchenin yöelämään, eivät vanhemmat voineet jäädä toimettomiksi. Ratkaisu oli reformipedagoginen sisäoppilaitos maaseudulla. Niin Erika ja Klaus saivat aloittaa uuden elämän Fuldan lähettyvillä Bergschule Hochwaldhausissa.

Aloitus uudessa koulussa ei ollut ankea: koulun ilmapiiri oli Klausin mukaan iloinen ja vapaa. Nuoret ihmiset elivät tiiviisti yhdessä kaukana vanhempien valvonnasta ja vapaina kaupunkielämän sovinnaisuuksista. Syntyi vahvoja ystävyyssuhteita. Suhteet opettajiin olivat toverillisia. Kun Erika sitten vuoden päästä palasi Müncheniin, halusi Klaus jatkaa elämää sisäoppilaitoksessa, mutta nyt kuitenkin toisessa koulussa. Valinta osui kansainvälises ti tunnetun pedagogin Paul Geheebin Odenwaldin kouluun. Koulun oppilasjoukko oli korostetun kansainvälistä. Siellä kohtasivat niin venäläisen emigrantin kuin amerikkalaisen pankkiirinkin jälkeläiset. Klaus Mann muistelee koulua suvaitsevaisuuden keitaana maassa, jossa pinnan alla kyti nationalismi ja rasismi. Paul Geheebin toiminta todisti uskosta demokratiaan: muun muassa kaikki yhteiselämää koskevat kysymykset hän jätti oppilaskokouksen päätettäviksi. (Mann, K. 1991, 98-104.)

Pikkuveli Golo Mann puolestaan vietti vuosia Kurt Hahnin johtamassa Salem-koulussa. Kurt Hahn oli kutsumuksellinen pedagogi, joka oli ottanut vaikutteita eräistä englantilaisista kouluista. Hän suhtautui oppilaisiin yksilöinä ja oli ilmeisen hyvä ihmistuntija. Opetus oli monipuolista. Myös Salem-koulussa oli foorumi, jolla opettajat ja oppilaat yhdessä puivat ajankohtaisia kysymyksiä. Muistelmissaan Golo Mann tunnustaa, että Kurt Hahn oli ihminen, joka vahvimmin ja pysyvimmin vaikutti häneen nuoruusvuosina. (Mann, G. 1991, 132-164.)

Mannin sisarukset viihtyivät reformikouluissa. On ilmeistä, että ne hengeltään poikkesivat olennaisesti perinteisistä kouluista. Kun tavallisessa koulussa ilmapiirin määrittivät pelätyt opettajat ja nöyryyttävä kasarmikuri, kohtasi reformikoulun oppilas kannustavan ja yksilöä kunnioittavan kulttuurin. Sitä täydensi sisäinen demokratia. Reformikoulu oli tietoinen vastalause keisarillisen Saksan koululle.

Perinteiseen kouluun kohdistuva kritiikki sai yhä kärkevämpiä muotoja. Kiinnitettiin huomiota siihen, että rangaistusten pelko, kova ja mielivaltainen kohtelu sekä epäonnistumisen uhka ajoivat jotkut oppilaat itsemurhaan asti. Erityisen vahvan vastenmielisyyden tunteen uudistajissa herätti ruumiillinen rangaistus. Pitikö koulun olla "rangaistuslaitos"? 
Tukea saatiin ruotsalaiselta Ellen Keylta, joka totesi piiskauskäytänteen takana olevan aikuisen puutteellisen itsekurin, kärsimättömyyden, arvokkuuden puutteen ja suoranaisen tyhmyyden. Oppilaan kärsimyksen toivat esiin myös monet ajan kaunokirjalliset teokset. (Scheibe 1999, 68-71; Key 2000 [1902], 96.)

Myös koulun oppiaineskeskeisyys herätti arvostelua. Kaiken lisäksi tarjotulla oppiaineksella ei ollut mitään tekemistä lasten elämän kanssa. Nämä vieraat oppisisällöt yritettiin saattaa lapsen mieleen kursailemattomalla pakolla. Koulu näytti vähät välittävän lapsen tarpeista tai vastaanottokyvystä. Eräs arvostelija, Berthold Otto, totesikin, että koulutyön pakonomaisuus tappoi lapsesta jaloimmat kehitysaihiot. (Scheibe 1999, 70-73.) Koulu oli kauhistuttavassa mitassa elämälle vieras.

Tarkastelen seuraavassa erityisesti saksalaisen reformiliikkeen juuria, ilmenemismuotoja ja tavoitteita. On kuitenkin huomattava, että pedagoginen uudistusliike oli 1800-luvun lopulta lähtien yleiseurooppalainen. Matti Koskenniemi mainitsee sen merkittävinä edustajina Leo Tolstoin, Cecil Reddien, Ovide Decrolyn, Jan Ligthartin ja Maria Montessorin. Yhdysvalloissa saman henkistä uudistusta ajoi John Dewey. Lähtökohdat eri maissa jonkin verran eroavat toisistaan. (Koskenniemi 1946, 43-50.) Lopuksi käsittelen lyhyesti saksalaisen reformipedagogiikan tuloa Suomeen. Akateemisen väen tiiviit suhteet Saksaan toivat eri alojen uudet virtaukset viivytyksettä Suomeen. Reformipedagogiikka ei ollut tästä poikkeus.

\section{Reformiliikkeen lähtökohtia}

Aatteellisen selkänojan reformipedagogiikka sai elämänfilosofiasta, suuntauksesta, joka hallitsi filosofista keskustelua vuodet 1880-1930 (Schnädelbach 1983, 172). Keskeinen suunnannäyttäjä oli Friedrich Nietzsche. Sanoessaan että Jumala on kuollut, Nietzsche kiteytti tuolloin ilmassa olleen ajatuksen. Aikaisemmin maailmankuvaa hallinneen Jumalan poistuminen muutti radikaalisti käsitystä sekä maailmasta että ihmisestä. Nietzsche ennakoi sen myötä alkavan uuden epookin, "ihmis-tulevaisuuden". Kun Jumala on haudassa, koittaa ihmiselle ylösnousemus. (Nietzsche 1981 [1885], 251.) Ihminen saavuttaa itsenäisyyden ja täyden vastuun elämästään. "Jumalan kuolema" ilmaisee vertauskuvallisesti kaikkien niiden yliaistillisten rakenteiden romahdusta, joille ihminen on perustanut elämänsä mielekkyyden. Arvot ja ihanteet samoin kuin usko historialliseen edistykseen ovat mennyttä. Seurauksena on tila, jota luonnehtii päämäärien puuttuminen ja sen myötä maailman kokeminen mielettömäksi. Ihminen ei enää saa kestäviä vastauksia olennaisiin miksi-kysymyksiin. (Simmel 1990 [1902], 19; Granier 1984, 33-36; Schnädelbach 1983, 203.)

Nietzsche vaatii jättämään metafyysiset harharetket. Elämää kantavat tekijät on löydettävä itse elämästä. Elämän tarkoitus on elämän rikastaminen, voimistaminen, kohottaminen ja elämään sisältyvien mahdollisuuksien toteuttaminen. (Simmel 1990 [1902], 45.) Tämä on lähtökohta, josta käsin ilmiöt ja teot voidaan jakaa tavoiteltaviin ja torjuttaviin, arvokkaisiin ja arvon vastaisiin. Nietzschen ajatus tarjoaa koulutyölle suuntaa antavan preferenssikehikon. "Elävä" tulee aina asettaa "kuolleen", "jäykän", "kaavamaisen", "mekaanisen" edelle. "Elämälle vieras" tai suorastaan "elämän vastainen" ovat ominaisuuksia, joiden tunnistaminen ei voi jäädä ilman toimenpiteitä. (Schnädelbach 1983, 172.)

Toinen merkittävä elämänfilosofi, Wilhelm Dilthey, arvostelee aikaisemmasta filosofiasta periytynyttä käsitystä, jonka mukaan ihminen tietämisen subjektina kohtaa maailman vain järkenä. Vastoin tätä Dilthey väittää ihmisen kohtaavan maailman kokonaisuutena, täytenä ihmisenä. Tahdonaktit, tunteet, arvostukset, havainnot ja ajattelu ovat erottamatto- 
masti toisiinsa kietoutuneet. Kohtaamisen tulos eli "kokemus" on kaikkien mainittujen tekijöiden summa. Eikä ihminen suinkaan ole maailmasta erillinen tarkkailija: ihmisen oleminen on aina maailmassa olemista. (Jung 1996, 34-38.)

Kasvatuksessa ei pidä keskittyä vain järkeen. Ajattelun taitojen kehittäminen joko uushumanistiseen tapaan kreikan ja latinan kielten opiskelulla tai uudemman ajattelun mukaan matematiikan harjoittamisella on ihmisen kokonaiskehityksen kannalta riittämätöntä. Painopisteen tulee olla luonteenkasvatuksessa. Esteettisen ja fyysisen kasvatuksen tulee saada niiden ansaitsema huomio.

Reformipedagogiikan ilmeisiä edeltäjiä kasvatusajattelun osalta ovat Rousseau ja Pestalozzi. Näiden ajattelijoiden lapsilähtöisyys elää renessanssin reformipedagogiikassa. Ellen Key menee vielä askeleen syvemmälle historiaan. Hän löytää Rousseaun ajatukset jo rans kalaiselta esseekirjailijalta Montaignelta, jonka mukaan lapsen ensimmäisen "kirjan" tulee olla luonto ja maailma kokonaisuutena. Vasta sitten tulkoot erityiset tieteenalat. Opiskelun ei tule olla annettujen lauseiden toistamista, vaan itsenäistä omaksumista. On nurinkurista odottaa lapsen ajattelevan ja puhuvan, ellei hänen anneta ajatella ja puhua. Opetus on sovitettava lapsen voimien ja kykyjen mukaan. (Key 2000 [1902], 122-129.)

Reformipedagogiikan edustajat olivat pääosin kasvatukselle omistautuneita toiminnan ihmisiä. He eivät laatineet kokoavia esityksiä liikkeestä. Kirjoitukset, joita he toimittivat julkisuuteen, olivat ohjelmallisia. Ensimmäinen yritys liikkeen kokonaishahmoksi oli Peter Petersenin Neueuropäische Erziehungsbewegung vuodelta 1926. Hermann Nohlin klassiseksi muodostunut esitys Die pädagogische Bewegung in Deutschland und ihre Theorie ilmestyi ensimmäisenä versionaan, jota Nohl sittemmin täydensi, vasta vuonna 1933 (Ofenbach 2002, 96.) Reformiliikkeen teorian muotoilijan osa lankesi henkitieteelliselle pedagogiikalle, jonka keskeinen edustaja Nohl oli (Thiersch 1978, 52)

Ensimmäinen maailmansota merkitsi pitkäaikaista puutetta, ponnistusta ja levottomuutta. Mutta ilman sitäkin yhteiskunnallinen tilanne oli epävakaa ja jännittynyt. Teollistuminen oli tuonut suurkaupunkeihin proletariaatin. Sen elinehdot poikkesivat jyrkästi siitä, mikä varakkaan porvariston osaksi tuli. Kärjistynyt luokkien vastakkaisuus halkaisi yhteiskunnan. Le Bon lisäsi levottomuutta tuomalla yleiseen keskusteluun "massojen kapinan" ja massalle ominaisen psykologian. Hän sanoi massan liikkeen olevan omaa laatuaan ja palautumaton yksilön ominaisuuksiin. Pelättiin, että jonakin päivänä suurkaupungin slummin asukkaat ryntäävät raivoavana laumana kadulle. Tässä liikkeessä yksilölliset identiteetit ja niiden myötä mahdolliset moraaliset pidäkkeet häviäisivät. Massoittuminen oli myös pedagogiikan ongelma. Oli täysi syy kysyä yleisemmin, millainen on yksilön ja yhteisön suhde. Reformipedagogeista kysymykseen paneutui erityisesti Peter Petersen. (Ofenbach 2002, 113-116.)

Uudistajat kulkivat klassisen pedagogiikan viitoittamaa tietä ja näkivät sivistyksen väylänä humaaniin yhteiskuntaan. Luokkayhteiskunnan ja massoittumisen oloissa tämä jäi väistämättä vain toiveeksi. Reformipedagogeilla ei ollut välineitä kriittiseen yhteiskuntaanalyysiin. (Thiersch 1978, 65-66.)

\section{Jugendbewegung - reformiaatteen kasvualusta}

Jugendbewegung eli suomeksi Nuorisoliike sai tosiasiallisen alkunsa jo 1890-luvulla, kun joukko Magdeburgin ja Steglitzin lukiolaisia teki neliviikkoisen patikkamatkan. Uuden harrastuksen vakiinnutti 1901 perustettu yhdistys, joka sai nimen "Wandervogel". Vähitellen 
patikoijien joukko kasvoi yhä uusilla koululais- ja opiskelijaryhmillä. Jugendbewegung on siten nimi, joka kokoaa alleen suuren joukon nuorisoyhdistyksiä. (Scheibe 1999, 38.)

Jugendbewegung on välitön vaikutteiden antaja reformikoulujen taustalla. Osa niiden opettajista tuli liikkeen piiristä. Klaus Mann, jolla oli omakohtaista kokemusta reformikouluista, pani merkille oppilaiden itsetietoisuuden. Oppilaat tiesivät olevansa nuoria ja olivat ylpeitä siitä. Nuoruudesta tehtiin ihannoitu elämänvaihe. Ei se ollut pelkkä välivaihe aikuisuuteen. Nuoruuden onnelliset vuodet jo taakse jättäneisiin suhtauduttiin halveksunnan sekaisella säälillä. Tämän uuden itsetietoisuuden innoittaja oli Nuorisoliike. Se oli romanttista kapinaa, joka vei nuoret suurkaupungeista vaelluksille maaseudulle. Iltaisin sytytettiin nuotio, soitettiin kitaraa, laulettiin kansanlauluja ja keskusteltiin nuoruuden innolla elämän suurista kysymyksistä. Nuoret hakivat autenttista elämää, jota ilman he kokivat jäävänsä porvarillisissa kaupunkikodeissaan. (Mann, K. 1991, 100-101.)

Herman Nohl on koonnut tuolloin ilmassa olleita ajatuksia seuraavaan tapaan. Vanhemmat olivat sietämättömiä. Heille tärkeää olivat turvallisuus ja elämässä menestyminen. Ihanteista oltiin aina valmiit luopumaan, mikäli oma etu sitä vaati. Ihmisiä arvioitiin tittelien ja varallisuuden perusteella. Merkitystä heidän lattealle elämälleen antoivat pienet nautinnot. (Nohl 1988 [1935], 19-20.) Elämäntavan onttoutta kuvasi muun muassa se, että vaikka muodollisesti oltiin kristittyjä, ei kristillisiä ihanteita juurikaan elämässä toteutettu (Key 2000 [1902]). Vaelluksista nuoret hakivat vapautta. Maailman oli avoinna edessä. Riitti kun käytti omia jalkojaan. Vaellus oli vapautta vanhemmista ja kodin ilmapiiristä. Eikä vapaa yhdessäolo toisten nuorten kanssa ollut merkitykseltään vähäisin. Luotiin omaa elämäntyyliä. (Nohl 1988 [1935], 18.)

Hermann Nohl sanoo Jugendbewegungin olevan aikansa merkittävin ja syvin pedagoginen ilmiö. Se muuttaa radikaalisti sukupolvien välisen suhteen. Se etsii tinkimättä uutta ihmisyyden ihannetta. Sen vaikutus ilmenee uutena suhteena nuorisoon, uutena pedagogisen vaikuttamisen tyylinä ja uutena tapana hahmottaa pedagoginen yhteisö. (Nohl 1988 [1935], 15.)

Nohl asettaa Nuorisoliikkeen laajaan historialliseen yhteyteen. Liike kumpuaa saksalaisesta romantiikasta ja antaa energiasysäyksen ylipäänsä kulttuurille. Se innoittaa tulevaisuuteen suuntaavia uudistusliikkeitä, yhtenä niistä reformipedagogiikka. Liikkeen pedagoginen merkitys on muun muassa siinä, että se nostaa vertaisryhmän keskeiseksi kasvattajaksi. Kun ryhmä valitsee johtajan omasta keskuudestaan, määrittyy johtajan ja johdetun suhde uudella tavalla. Uusi yhteisöllisyys ilmenee myös toverillisuudessa, joka liittää tytöt ja pojat toisiinsa. Tytöt eivät enää ole pojille vain joko etäisiä puolisoehdokkaita tai vieteltäviä piikatyttöjä. Nuoret, joiden oli vaikea kunnioittaa vanhempiaan ja näiden elämäntapaa, ottivat elämän omiin käsiin. Siitä he kantoivat tietoisen vastuun. Nohlin mukaan vastuu haluttiin sittemmin ulottaa koko kansakuntaan tavoitteena kansakunnan uudistaminen. (Nohl 1988 [1935], 18-22.)

Nohlin kuvaus liikkeestä on innostunut ja ihannoiva. Kuvaus vastaa käsitystä, jonka Nohl sai liikkeen alkuvaiheessa. Yllättäen myöhempi luonnehdinta samassa kirjassa on tyrmistynyt ja pahaa aavistava. Lähestyttäessä 30-lukua kulttuurinen ja poliittinen ilmapiiri muuttui. Auktoriteetti teki paluun. Pidettiin oikeana jäsentää ihmisten välisiä suhteita johtaja-seuraajat, mestari-oppilaat tyyppisillä käsitepareilla. Tämä virta tempaisi mukaansa myös Nuorisoliikkeen. Kun aikaisemmin vertaissuhteet ja tasa-arvo olivat itsestään selvyys, toi uusi vaihe sotilaallisen kurin ja johtajan ehdottoman auktoriteetin. Käänne oli silmiinpistävä. (Nohl 1988 [1935], 72.)

Tasa-arvoa vieroksuvan asenteen ilmentymänä Nohl mainitsee runoilija Stefan Georgen ympärille ryhmittyneen nuorten miesten piirin. Se palvoi sankaruutta ja vaarojen täyttämää 
elämää. Tasa-arvon se torjui: ihmiset jakautuvat luonnostaan "jaloihin" ja "rahvaaseen". (Nohl 1988 [1935], 72; Löwith 1989, 19-20.) Tälle joukolle sota oli elämää parhaimmillaan.

Klaus Mann suhtautuu Nuorisoliikkeeseen varauksellisesti. Hän näkee siinä keskenään ristiriitaisia elementtejä. Kukapa voisi paheksua patikointia reppu selässä, innostusta vanhoihin lauluihin ja tansseihin, romanttista kapinaa kaupunkien "mekaanista" elämäntyyliä kohtaan. Mutta Mann näkee pinnan alla myös taantumuksellisia nationalistisia aihioita. (Mann, K. 1991, 100.)

Jugendbewegung ei jäänyt ympäristöltä huomaamatta. Oli luonnollista, että nuorisotyötä tekevät järjestöt niin poliittisten puolueiden kuin kirkkojenkin piirissä poimivat elementtejä menestyneestä mallista. Järjestöjen työssä ilmeni Nuorisoliikkeen piirteitä, mutta tavoitteet eivät olleet nuorten määrittämiä. (Nohl 1988 [1935], 24.) Kansallissosialistien noustua valtaan silloinen Nuorisoliikkeen organisaatio purettiin (Scheibe 1999, 39).

\section{Reformipedagogiikka koulun uudistajana ja demokratisoijana}

Nohl kiteyttää reformiliikkeen läpikäyvän ajatuksen seuraavasti: tavoitteena on uusi ihminen uudenlaisessa yhteisössä. Tuo yhteisö luodaan elämänpiiriksi, jossa kasvatuksella on parhaat onnistumisen edellytykset. Sanottakoon sitä pedagogiseksi elämänyhteisöksi. Se on yhteisö, jossa toteutuvat Jugendbewegungin parhaat piirteet. Gustav Wyneken toi hyvin esiin Jugendbewegungin ja reformiliikkeen läheisen yhteyden kehottamalla nuorisoa palaamaan romanttisilta vaelluksilta kouluun. Koulusta oli määrä rakentaa nuorisokulttuurin omin paikka. (Nohl 1988 [1935], 78, 82.)

Uudet koulut sijoitettiin tarkoituksella maaseudulle. Suurkaupungit nähtiin lian ja hälinän täyttäminä paheiden tyyssijoina. Koulujen oli määrä olla uuden elämäntavan alkusoluja. Kun tuohon aikaan koottiin ihmisiä ihanteellisten tunnusten alla perustamaan siirtokuntia uudelle mantereelle, niin eräänlaisia siirtokuntia olivat uudet koulutkin, mutta oman maan rajojen sisällä. Keskeisiä koulunperustajia Wynekenin ohella olivat Hermann Lietz sekä jo aikaisemmin mainitut Kurt Hahn ja Paul Geheeb. Monelle uudistajalle tärkeän esikuvan muodosti englantilainen sisäoppilaitos Abbotsholme. (Nohl 1988 [1935], 78, 84.)

Katseet kääntyivät Englantiin muun muassa siksi, että saksalaisen koulun kansalaiskasvatus koettiin epätyydyttäväksi. Perinteinen saksalainen koulu oli osa preussilaista virkamiesjärjestelmää. Sille oli ominaista jäykkä esimies-alaissuhde: ylemmällä oli ehdoton auktoriteetti ja alemmalla velvollisuus totella. Hierarkiassa ylemmän päätöksiä ei saanut kyseenalaistaa. Niin kansalaisen kuin koulun oppilaankin osa oli passiivinen alistuminen. Tämän kanssa linjassa saksalainen koulu kasvatti selkärangattomia tottelijoita. Englantilaisten koulujen kasvatus oli toista maata. Sen nähtiin aikaansaavan kasvateissa itsenäisyyttä ja luonteenlujuutta. Nojaaminen auktoriteettiin ja pakko eivät sellaisia ominaisuuksia tuottaneet. Friedrich Förster totesi painokkaasti, että koko elämänkulkua määräävä keskeinen voima on luonne. Luonteen kasvatuksessa koulu ei saanut epäonnistua. (Nohl 1988 [1935], 67; Scheibe 1999, 213.)

Reformikoulut näkivät tärkeimmäksi tehtäväkseen luonteenkasvatuksen. Tavoiteltavia luonteen piirteitä olivat itsenäisyys ja luonteenlujuus. Luonteenlujuus oli esillä jo Herbartilla, joka ymmärsi sillä vahvaa taipumusta valita hyvä ja oikea pahan ja väärän sijasta (Ofenbach 2002, 102). Merkittäviä olivat myös aloitteellisuus, vastuuntunto ja itsekuri. Tavoitteet olivat ylevät, mutta keinot eivät olleet itsestään selviä. Kasvatuksen käytettävissä ei ollut tuolloin eikä ole nytkään yksiselitteisiä ja täsmällisiä keinoja määrättyjen tavoitteiden 
saavuttamiseksi. Keinojen ongelmaan paneutunut Friedrich Förster totesi, ettei luonnetta pidä kasvattaa karkealla ulkoisella vaikuttamisella. Se mihin oli totuttu, toisin sanoen moralisointi, ankarat rangaistukset, tyly oikaiseminen, pilkka ja häpeään saattaminen, eivät tulleet kysymykseen. Sen sijaan oli lähdettävä kasvatin sisäisistä pyrkimyksistä, ennen kaikkea kunniantunnosta ja itsearvostuksesta. Vetoaminen kasvatin kunniantuntoon oli tie toivotunlaiseen luonteen kehitykseen. (Scheibe 1999, 220.)

Jotta voisi kasvaa vastuuntuntoiseksi, pitää yksilön olla subjekti omassa elämässään. Tämän tulee ulottua myös työelämään. Yksilöllä tulee olla sananvaltaa niin työn suunnittelussa kuin suorittamisessakin. Uudistajat korostivat subjektia, mutta näkivät vaarana myös sen liiallisen asettamisen etualalle. Haluttiin välttää Ellen Keyn väitetty rajaton individualismi. Yksilön tuli olla myös aidosti yhteisön jäsen. Millaisessa yhteisössä yksilö on sekä subjekti että osa kokonaisuutta? Vaatimusten nähtiin täyttyvän työyhteisössä. Siinä yksilö toimii koordinoidusti yhdessä muiden kanssa ja tuntee yhdessä tekemisen ilon. Yksilö sitoutuu vapaaehtoisesti - ei pakolla - työyhteisön tavoitteisiin. Eikö siis koulutkin pidä järjestää eräänlaisiksi työyhteisöiksi, uudistajat kysyivät. (Nohl 1988 [1935], 65-70.) Keskeinen juonne reformipedagogiikassa onkin työkoulun idea. Työkoulun kaksi keskeistä suunnannäyttäjää, Georg Kerschensteiner ja Hugo Gaudig, antavat kuitenkin ajatukselle hyvin erilaiset tulkinnat: kun Kerschensteiner korostaa fyysistä työtä ja tuotosta, tulkitsee Gaudig työn vapaaksi henkiseksi toiminnaksi, jonka on määrä avata tie täyteen henkiseen vapauteen (Scheibe 1999, 180-181, 190-191).

Reformipedagogien ponnistukset luonteen kasvatuksessa voidaan tulkita pyrkimykseksi luoda perustaa demokratialle poliittisena järjestelmänä. Järjestelmä edellyttää itsenäisiä ja arvostelukykyisiä kansalaisia, jotka säännöllisin väliajoin ovat valmiit valitsemaan vaaleilla päättäjät. Kansalaisilla on demokraattisessa järjestelmässä oma osansa ja heidän oletetaan myös tekevän oman osansa. Toivottujen asenteiden juurtuminen vaatii harjoitusta. Muodossa tai toisessa reformikouluissa toteutettiin oppilaiden itsehallintoa. Pedagogisesta näkökulmasta se harjaannuttaa oppilaat vastuuntuntoon. Lisäksi järjestys, jota oppilaat itse ylläpitävät, koetaan oppilaiden taholta sitovaksi ja velvoittavaksi. Myös opettaja-oppilassuhde saa uuden luonteen, kun sekä opettaja että oppilas ovat saman eettisen yhteisön jäseniä. Entisen antagonistisen suhteen sijaan astuu luottamus. (Scheibe 1999, 247.)

Jos oppilas ymmärretään subjektiksi, tulee hänelle antaa mahdollisuus toimia subjektina. Se ei tullut kysymykseen aikaisemmassa epäsymmetrisessä opettaja-oppilassuhteessa. Kaikkialle koulun elämässä ulottuva autoritaarisuus tuli tunnistaa ja purkaa. Se vaati vallitsevan pedagogisen suuntauksen, herbartilaisuuden, kriittistä tarkastelua. Herbartilaisuudessa yhdistyivät autoritaarisuus ja tieteellisyys. Opettaja ehdottomana auktoriteettina siirsi tiedollista perintöä uudelle sukupolvelle. Tieteellisyyden vaatimukseen herbartilaisuus vastasi systemaattisuudella ja assosiaatiopsykologialla. Tieteellisyyden korostus loi mielissä kuvan neutraalista opista. Arvostelijat tarttuivat toteutuksen kaavamaisuuteen sekä jäykkään oppiaineskeskeisyyteen. Välitön kokemus ja elävyys jäivät opetuksessa tavoittamatta. (Thiersch 1978, 50-51.)

Reformipedagogit pitivät tärkeänä välitöntä suhdetta luontoon. Kokonaisvaltaisella kaikin aistein tapahtuvalla luonnon kohtaamisella oli Hermann Lietzin mukaan kasvavalle suuri merkitys. Ruumiillisen työn katsottiin olevan ideaalinen tapa kokea luonto täydessä mitassaan. Gustav Wyneken totesikin, että työ puutarhassa ja työpajoissa on kasvatuksen välttämätön osa. Sen tulee sisältyä myös akateemisiin opintoihin tähtäävään ohjelmaan. Lietz tuo painokkaasti esiin ruumiillisen työn sosiaalisen merkityksen: joka ei ole oppinut tekemään ruumiillista työtä rinta rinnan toisten kanssa hikoillen, sille jää enemmistö kans saihmisistä tuntemattomiksi ja käsittämättömiksi. Lietz nostaa esiin ajatuksen yhteiskunta- 
rauhasta. Se edellyttää sivistyneistön ja ruumiillisen työn tekijöiden vastavuoroista toistensa kunnioittavaa ymmärtämistä. Jos sivistyneistö laajentaa elämänpiiriään ruumiillisella työllä, on kättensä työllä elävillä vastaavasti oikeus saada osansa aidosta sivistyksestä. (Scheibe 1999, 120-122.) Reformipedagogit eivät suinkaan olleet tietämättömiä yhteiskuntansa luokkaluonteesta.

Kun herbartilaisen ajattelun mukainen koulutyö oli opettaja-, oppiaine- ja oppikirjajohtoista, pyrittiin reformipedagogiikassa määrätietoisesti siirtämään painopistettä opettajasta oppilaaseen uusilla opetusmuodoilla. Ryhmätyöskentely, itsenäinen työ, yhteiset keskustelut, leikit ja yhdessä järjestetyt juhlat tekivät oppilaista aktiivisia toimijoita. Oppiainekeskeisyys sai tehdä tilaa projekteille. Ideaalina oli kokonaisopetus, ajatus että oppiaineiden asemesta luodaan lapsen kokemusmaailman kannalta merkityksellisiä asiakokonaisuuksia. Oppiaineet saivat niissä alisteisen aseman. (Iisalo 1989, 230-231.)

Peter Petersen luopui perinteisestä vuosiluokkamallista. Sen sijaan muodostettiin useita ikäluokkia käsittäviä ryhmiä. Vanhemmille oppilaille tuli luontevasti nuorempien auttajan osa. Ryhmän jäsenet kasvattivat toinen toistaan. (Iisalo 1989, 228.) Malli toteutti Jugendbewegungin ajatuksen nuorista toistensa kasvattajina.

Vaikka Petersenin Jena-koulu sai jatkaa läpi kansallissosialistisen ajan, muut reformikoulut pääosin lakkautettiin. Lapsikeskeisyys ja vapauden korostus eivät sopineet kansallissosialistisen kasvatuksen lähtökohdiksi. (Iisalo 1989, 226.)

\section{Myöhästynyt kansakunta}

Reformipedagogien pyrkimyksiä demokratian edistämiseksi on kiinnostavaa tarkastella sekä tuolloisen yhteiskunnan että pitkän historiallisen kehityksen valossa. Demokratiaa toteuttavat instituutiot olivat heiveröisiä niin keisarillisessa Saksassa kuin sodan jälkeen perustetussa Weimarin tasavallassakin. Helmuth Plessnerin tunnetun analyysin mukaan Saksa oli "myöhästynyt kansakunta". Ranskaan ja Englantiin verrattuna Saksa oli auttamattoman jälkijättöinen useilla ulottuvuuksilla.

Plessneriä seuraten saksalaiset ovat aina vierastaneet läntisiä muodollisia rationaalisia malleja. Valtiota ei ole haluttu nähdä muodollisena rakenteena. Sen sijaan on puhuttu "Saksan kansasta". Ilmaisu viittaa orgaaniseen ykseyteen, johonkin joka on alkuperäistä ja ainutkertaista. Mainittu ykseys torjuu kaikki ulkoa tulevat muodot ja hyväksyy vain järjes tyksen, joka kasvaa siitä itsestään. Jo germaanit torjuivat roomalaiset vaikutteet. Keskiajan lopulla Luther uhmasi Rooman kirkkoa. Edes valistus ei juurikaan jättänyt jälkiä saksalaiseen yhteiskuntaelämään huolimatta merkittävistä saksalaisedustajistaan. Kun Ranska ja Englanti vähitellen loivat demokratian vaatimia instituutioita, pitäytyi saksalainen maailma vuosisatojen takaisissa traditioissa. (Plessner 1988, 52-64.)

Kourallinen reformikouluja ei tietenkään voinut kääntää pitkäaikaista trendiä. Ne eivät kyenneet tekemään saksalaisista tinkimättömiä demokratian puolustajia. Kouluissa kuitenkin uskottiin, että niiden kasvateista tulee Saksalle uudenlaisia johtajia. Erityisen avoimesti tämän toi esiin Kurt Hahn. Salem-koulun oppilaan Golo Mannin mukaan Hahnin tavoite oli kasvattaa aikaisempaa parempia johtajia, moraaliltaan ja luonteeltaan moitteettomia. Kiipijät ja opportunistit olivat Hahnin näkökulmasta epäonnistumisia. Mann toteaa, että Hahn yliarvioi koulun merkityksen: hyvälläkin koululla on rajansa. (Mann, G. 1991, 145146.) Golo Mann on oikeassa, reformikoulujen panos ei estänyt demokratianvastaisen hallituksen valtaan nousua vuonna 1933. 


\section{Reformipedagogiikka Suomessa}

Klaus Mannin romaanin Pako pohjoiseen avausluvun asetelma ei liene aivan todellisuudelle vieras: suomalainen ystävystyy 30-luvun Berliinissä saksalaisen opiskelutoverinsa kanssa ja pyytää tämän perheensä vieraaksi Suomeen (Mann, K. 1983). Saksaan lähdettiin opiskelemaan jo ennen Suomen itsenäistymistä eikä tämä liike katkennut kansallissosialistisen hallituksen valtaan nousuun. Esimerkiksi kesällä 1914 sodan uhasta huolimatta Yrjö Reenpää teki anatomisia harjoituksia Berliinissä ja Jalmari Salomaa tutkaili Leipzigissa mahdollisuuksia väitöskirjan tekoon (Reenpää 1974, 33; Salomaa 1954, 176). Opintomatka Saksaan 1935 oli välttämätön tulevalle kasvatustieteen professorille Matti Koskenniemelle (Majaniemi 2007). Laiva kulki säännöllisesti Helsingistä Saksaan ja toi palatessaan uudet aatteet.

Taimo Iisalon mukaan reformipedagogiikan ajatuksia tunnettiin Suomessa jo vuoden 1900 tienoilla. Herbartilaisuus tuskin oli ehtinyt vakiinnuttaa asemansa, kun reformipedagogiikka jo puhalsi niskaan. Koulun monin tavoin vakiintunutta ja sidottua järjestystä reformiliike ei kyennyt horjuttamaan, mutta yksittäiset opettajat saattoivat työssään toteuttaa uudistusliikkeen suosimia työtapoja. Omalla vaatimattomalla tavallaan kotiseutu- ja ympäristöoppi toimi esimerkkinä opetuksen integroinnista. (Iisalo 1989, 232-237.)

Vähitellen reformipedagogiikka alkoi näkyä myös suomalaisessa kasvatusopillisessa kirjallisuudessa. Tuon tästä esimerkkinä A.K. Ottelinin teoksen Pedagogikens grunddrag. Ensimmäinen laitos ilmestyi jo 1916 ja toinen didaktiikalla laajennettuna 1931. Esipuheessa tekijä toteaa, että "uusi koulu" ansaitsee tulla huomioon otetuksi, vaikkakaan käsillä oleva teos ei anna siitä seikkaperäistä kuvausta. Kirjoittaja tunnustaa huomanneensa "uuden koulun" nuorekkaan halun vanhan purkamiseen. Sen halu lähteä uusille urille on ilmeinen. (Ottelin 1931.) Ottelin antaa ymmärtää, että oli jo tullut tavaksi puhua "vanhasta" ja "uudesta" koulusta.

Ratkaisevaa läpimurtoa reformipedagogiikka sai odottaa aina sotavuosiin asti. Siinä näytteli keskeistä osaa uuden ajattelun edustajan Matti Koskenniemen saama tehtävä. Jatkosodan aikana luutnantti Koskenniemi sai johdettavakseen juuri perustetun Paltamon väliaikaisen opettajaseminaarin. Paltamon seminaariin kerättiin valloitetun Itä-Karjalan alueelta nuoria, joilla oli riittävä pohjakoulutus ja jonkinlainen suomen kielen taito. Heistä oli määrä kouluttaa suomalaisia kansakoulunopettajia, jotka koulutuksen päätyttyä palaisivat opettajina Itä-Karjalaan. Koskenniemi tuskin olisi voinut saada mieluisampaa tehtävää. Hänestä koulupedagogiikka vaati olennaista muutosta ja nyt hän pääsi kouluttamaan opettajia uuden koulun hengessä. Kun seminaari sitten muutti Jämsään ja sieltä Raumalle, sai Koskenniemi käyttöönsä kokeilun mahdollistavan harjoittelukoulun (Koskenniemi 1983, 33-49.)

Koskenniemen Kansakoulun opetusoppi edustaa reformipedagogiikan läpimurtoa Suomessa. Ensimmäisen painoksen alkulause on päivätty tammikuulle 1944, jolloin jatkosota oli vielä täydessä käynnissä. Toinen korjattu laitos ilmestyi 1946. Alkulauseessa Koskenniemi viittaa teoksen sisältöön keskeisesti vaikuttaneisiin suomalaisiin Salomaahan, Liliukseen ja Holloon sekä saksalaiseen Peter Peterseniin. (Koskenniemi 1946, 5).

Kansakoulun opetusoppi on kauttaaltaan reformipedagogisen hengen läpäisemä. Samalla se pitkin matkaa hienovaraisesti arvostelee herbartilaisia lähtökohtia. Sen sijaan Koskenniemi lainaa hyväksyvästi Jan Ligthartia, jonka mukaan lasta ei pidä ajatella valkeana paperina, jonka kasvattaja kirjoittaa täyteen. Todellisuudessa lapsi on täyteen kirjoitettu arkki, jota kasvattajan on opittava lukemaan. (Koskenniemi 1946, 42.) Lapsilähtöisyys on ehdoton alkuasetus. 
Kasvatuksen päämäärä on Koskenniemen mukaan persoonallisuus. Sillä tarkoitetaan yksilöä, joka suhtautuu myönteisesti ympäristöönsä ja sen omaksumiin arvoihin sekä pyrkii niitä toteuttamaan. Määrittely sisältää vahvan yhteisöllisen korostuksen. Koskenniemelle ihminen on sosiaalinen olento, joka voi elää vain toisten ihmisten kanssa ja joka on totutettava toimimaan yhteiseksi hyväksi. Ihanne vaatii ennen kaikkea tahto- ja tunne-elämän kasvatusta. (Koskenniemi 1946, 15, 42.)

Opetuksen keskeisinä periaatteina Koskenniemi tuo esiin omatoimisuuden, elämänläheisyyden ja havainnollisuuden. Oppilaiden omatoimisuudelle on annettava tilaa. Koulutunnin kulku ei saa olla yksityiskohtia myöten opettajan suunnittelema ja valvoma. Opettajan asema vaatii siten uudelleen arviointia. (Koskenniemi 1946, 39, 78-99.)

Kirjan toisen painoksen alkulauseessa Koskenniemi arvelee, että teosta "tultaneen käyttämään oppikirjana opettajainvalmistuslaitoksissa". Yliopistojen liepeille perustetuissa opettajakorkeakouluissa niin luultavasti tapahtuikin. Kansakoulut siirtyivät hitaasti reformipedagogiikan piiriin, vaikka jo 1944 kouluhallitus Alfred Salmelan toimesta kehotti jokaista maan kansakoulua hankkimaan mainitun teoksen kirjastoonsa (Koskenniemi 1983, 44). Mutta entä oppikoulut, kaksijakoisen koulujärjestelmän toinen haara? Sodan jälkeen oppikoulun suosio kasvoi vuosi vuodelta. Näin siitä huolimatta, että oppikoulun opetustyyli oli pelkistetyn karu, mikä ilmeni muun muassa runsaana luokalle jäämisenä ja keskeyttämisinä. Olisiko oppikoulu ollut korjattavissa paremmalla pedagogiikalla? Ja enemmänkin, voisiko paremmalla pedagogiikalla tarjota oppikoulun sisältöjä koko ikäluokalle? Yhä useamman päättäjän mielessä väikkyi suuri koulu-uudistus. Tuskin on kaukaa haettua olettaa, että reformipedagogiikka osaltaan rohkaisi koulun uudistajia radikaaliin ratkaisuun. Peruskoulu aikanaan demokratisoi suomalaisen koulujärjestelmän.

Koskenniemi ei ollut ainoa reformipedagogiikan puolestapuhuja Suomessa, mutta kiistatta eräs vaikutusvaltaisimmista. Peruskoulua pohjustavissa komiteoissa hän oli pedagogisena asiantuntijana itseoikeutettu jäsen. Kun komiteoihin kutsuttiin eri intressiryhmien edustajia, ei sisäisiä jännitteitä voinut välttää. Eri suuntiin vetävien jäsenten takia komiteoiden lopputulokset eivät olleet ennakoitavissa. Koskenniemi muun muassa pani merkille, miten vaikeaa oli saada tieteenalojen edustajat ymmärtämään, että aineen hallinnan lisäksi opettaja tarvitsee myös taidon opettaa ja että tärkeintä ovat oppilaat. (Koskenniemi 1983, 114, 137.)

\section{Lopuksi}

Miten reformipedagogiikan kävi? Sodan vuodet eivät muualla kuin Suomessa olleet sille suosiollisia. Jokaisella historiallisella liikkeellä on kypsä kukoistusvaiheensa, jolloin sen piirteet näyttäytyvät tarkkailijalle selvästi erottuvina. Kun liike heikkenee, se ehkä sulautuu muihin liikkeisiin tai muuntuu yhä kauemmaksi alkuperäisestä etääntyviksi johdannaisiksi.

Herman Nohl, joka laati tunnetun ja minunkin edellä referoiman kirjallisen esityksen reformiliikkeestä, kirjoitti sodan jälkeen 1949 kirjaansa jälkisanat. Takana oli kansallissosialistinen hallinto ja toinen maailmansota. Mitä Nohl tuossa tilanteessa ajatteli? Hän hahmottelee kasvatuksen suuria linjoja. Nohl erottaa kaksi pedagogista linjaa, jotka ovat nähtävissä aina antiikista asti. Toinen lähtee yksilöstä, hänen potentiaaleistaan ja pyrkimyksistään, joiden edistämisen kasvattaja ottaa tehtäväkseen. Mutta yksilökeskeisessä pedagogiikassakin lopulta ponnistetaan kollektiivisesta kulttuuriperinnöstä. Jotta kasvatus voitaisiin saattaa onnistuneesti päätökseen eikä se jäisi puolitiehen, tulee Nohlin mukaan kansallisen perinnön olla ehjä ja täysipainoinen. Yksilökeskeisen pedagogiikan edustajaksi Nohl 
nimeää Sokrateen. Toinen suunta - edellisen kanssa jännitteisessä suhteessa - ottaa lähtökohdaksi yhteiskunnan. Miten ensin rakennetaan optimaalinen yhteiskunta ja miten kasvatuksella saatetaan yksilöt palvelemaan sen tarpeita. Ei kysytä, onko yksilö onnellinen, vaan miten hän parhaiten palvelee kokonaisuutta. Nohl tulkitsee Platonin ajatelleen tähän tapaan. Nohl huomauttaa, että senkin, jonka lähtökohta on yhteiskunta, on syytä muistaa, että kollektiivin pysyvä olemassaolo on lopulta yksilöiden moraalisen tietoisuuden ja rohkeuden varassa. Yksilön ja yhteisön suhde on kehämäinen. Kahden mainitun suunnan välillä on kasvatustyön toteutuksessa löydettävä tasapainotila. (Nohl 1988, 280-283.) Nohlin huomautus jatkuvasta tasapainon hakemisesta osuu Suomeenkin.

Vieläkin tapahtumien nopeudesta hämmästyneenä Nohl muistaa, miten keväällä 1933 yksilökeskeinen pedagogiikka vaihtui hetkessä kollektiivipedagogiikkaan. Totalitaarinen valtio valjasti kasvatus- ja koulutusinstituutiot palvelemaan suoraan tarpeitaan. (Nohl 1988, 283.) Weimarin tasavalta oli tukenut reformipedagogiikkaa. Sodan jälkeen kaikki oli ajateltava uudelleen alusta lähtien. Saiko reformikoulu tällöin uuden tilaisuuden? Se riippui ratkaisevasti paikallisista olosuhteista. Asialleen omistautuneiden pedagogien lisäksi tarvittiin poliitikkojen, kouluviranomaisten ja opettajajärjestöjen aktiivinen tuki. (Tenorth 1999, 439, 444.)

Reformikoulu oli parhaimmillaan pakoton, suvaitsevainen ja humaani. Se piti arvossa yksilöä ja tarjosi mahdollisuuden monipuoliseen itsensä kehittämiseen. Reformikoulu oli eräänlainen utooppinen ikkuna demokraattiseen elämänmuotoon, siihen, johon ympäristö ei vielä ollut valmis.

\section{Kirjallisuus}

Granier, Jean 1984. Nietzsche. Käänt. Alessandro Serra. Milano: Feltrinelli Editore.

Iisalo, Taimo 1989. Kouluopetuksen vaiheita. Helsinki: Otava.

Jung, Matthias 1996. Dilthey zur Einführung. Hamburg: Junius Verlag.

Key, Ellen 2000 [1902]. Das Jahrhundert des Kindes. Käänt. Francis Maro. Weinheim und Basel: Beltz Verlag.

Koskenniemi, Matti 1946. Kansakoulun opetusoppi. Helsinki: Otava.

Koskenniemi, Matti 1983. Niin mielelläni vielä. Muisteluksia. Haastattelijat ja toimittajat Jussila, Juhani ja Kansanen, Pertti. Helsinki: Helsingin yliopiston opettajankoulutuslaitos. Tutkimuksia 12.

Löwith, Karl 1989. Mein Leben in Deutschland vor und nach 1933. Ein Bericht. Frankfurt am Main: Fischer Taschenbuch Verlag.

Majaniemi, Janne 2007. Älykkyystutkimuksen rajat - Matti Koskenniemen opintomatka kansallissosialistiseen Saksaan 1935. Teoksessa Tähtinen, Juhani \& Skinnari, Simo (toim.), Kasvatus- ja koulukysymys Suomessa vuosisatojen saatossa. Helsinki: Suomen kasvatustieteellinen seura, 473-496.

Mann, Golo 1991. Erinnerungen und Gedanken. Eine Jugend in Deutschland. Frankfurt am Main: Fischer Taschenbuch Verlag.

Mann, Klaus 1991. Der Wendepunkt. Ein Lebensbericht. Hamburg: Rowohlt Taschenbuch Verlag.

Mann, Klaus 1983. Pako pohjoiseen. Käänt. Klaus Karttunen. Helsinki: Otava.

Nietzsche, Friedrich 1981 [1885]. Näin puhui Zarathustra. Käänt. J.A. Hollo. Helsinki:

Otava. 
Nohl, Herman 1988 [1935]. Die pädagogische Bewegung in Deutschland und ihre Theorie. Frankfurt am Main: Vittorio Klostermann.

Ofenbach, Birgit 2002. Peter Petersen. Allgemeine Erziehungswissenschaft. Darmstadt: Wissenschaftliche Buchgesellschaft.

Ottelin, Ahti Konrad 1931. Pedagogikens grunddrag. Helsingfors: Söderström \& Co förlagsaktiebolag.

Plessner, Helmuth 1988. Die verspätete Nation. Ueber die politische Verführbarkeit bürgerlichen Geistes. Frankfurt am Main: Suhrkamp.

Reenpää, Yrjö 1974. Ajateltua ja koettua. Helsinki: Otava.

Salomaa, Jalmari 1954. Eräs lapsuus ja nuoruus. Helsinki Werner Söderström osakeyhtiö.

Scheibe, Wolfgang 1999. Die reformpädagogische Bewegung 1900-1932. Weinheim und Basel: Beltz Verlag.

Schnädelbach, Herbert 1983. Philosophie in Deutschland 1831-1933. Frankfurt am Main: Suhrkamp.

Simmel, Georg 1990 [1902]. Schopenhauer und Nietzsche. Hamburg: Junius Verlag.

Tenorth, Heinz-Elmar 1999. Nachwort. Reformpädagogik und ihre Historiographie und Analyse. Teoksessa Scheibe, Wolfgang, Die reformpädagogische Bewegung. Weinheim und Basel: Beltz Verlag. 438-449.

Thiersch, Hans 1978. Die hermeneutisch-pragmatische Tradition der Erziehungswissenschaft. Teoksessa Thiersch, Hans, Ruprecht, Horst \& Hermann, Ulrich, Die Entwicklung der Erziehungswissenschaft. München: Juventa Verlag, 11108.

YTT, Jyrki Hilpelä on eläköitynyt tutkija Joensuusta. 